\title{
CLOSE OF THE CRETACEOUS AND OPENING OF EOCENE TIME IN NORTH AMERICA ${ }^{1}$
}

\author{
BY HENRY FAIRFIELD OSBORN
}

\section{(Presented before the Paleontological Society December 31, 1913)}

In introducing this symposium on a critical point in geologic time emphasis must first be laid on the fact that the Periods were defined during the last century by European paleontologists, and that American events can be dated only by comparison of American with European faunas and floras, unless simultaneous and world-wide diastrophic movements can be demonstrated to have occurred.

The demarcation between the Cretaceous and the Eocene periods of Europe rested first on the work of Deshayes on the extinct molluscan fauna of the Paris basin. It gradually developed in definition and clearness under Lyell, D'Orbigny, Mayer, and Eymar. Gradually also vertebrate reptiles and mammals entered into the problem, and the formations along the northern coast of Europe and Belgium, with their contained marine fossils, served to define the Mcestrichtien stage (Dumont, 1849), while in the north another late Cretaceous phase typified the Danien stage (Desor, 1846). According to Haug (1912), the Danien overlies the Mestrichtien concordantly, and thus closes the Cretaceous period. 'The fauna is purely marine and exclusively Cretaceous. Some authors also place the overlying Montien in the Cretaceous.

The Mastrichtien as exposed in Belgium includes a rich reptilian fauna, which comprises several kinds of mosasaurs, great marine turtles, iguanodont dinosaurs, and their enemies, the carnivorous dinosaurs. This is our last view of the dinosaur life of Europe. The Mcstrichtien fauna has not been closely correlated up to the present time with an American fauna. According to Williston, it is subsequent to any known American mosasaur fauna, and this author regards the Mastrichtien as a lower phase of the Danien. It is to be noted also that no late Cretaceous terres-

1 Manuscript received by the Secretary of the Geological Society June 12, 1914.

This paper is an introduction to the symposium on this subject held at the Princeton meetlng of the Society December 31, 1913, and January 1, 1914. 
trial fauna is known in Europe corresponding with the Danien time epoch or with the "Lance" fauma of North America.

The very ancient Paleocente formations of northern Europe, including the problematic Monlien epoch and the well defined Thanetien marine phase, are along the sea borlers, and consequently are unfarorable to the preservation of mammalian life. They contain no dinosaurs or mosasaurs. Among these are the sables de liklly, seashore sands containing many marine mollusks which are similar to those in the Sables de Bracheux, another Paleocene formation. In France, however, as long ago as 1841, one fluviomarine formation yjelded a single mammal, Arctocyon primsevs, in bels correlated in time with the Thanétien. At a slightly subsequent period of Thanolien time a river-borne formation includes the celebrated mammalian fauna of (ermay and the single surviving ('retaceous reptilian type Cham psosaurus.

Without exception it may be said that all the paleontologists of Europe have considered the Cretaceous as the perior of the final extinction of the terrestrial dinosaurs and the marine mosasaurs; and they have similariy clefined the Paleocene not only by its new forms of marine mollusca, but by the survival of the characteristic plagiaulacid mammals of the Mezozoic and the first general appearance of a primitive mammalian land fauna, which broadly corresponds with a similar Puerco-Torrejon-Fort Union fauna in North America.

The discussion to which we are deroting this session of the Palcontological Society is of great interest and importance because a number of eminent American paleobotanists and geologists, as well as certain invertebrate paleontologists, are of the opinion that the close of Cretaceous time occurred long before the extinction of certain great families of terrestrial dinosaurs, and that as a consequence the opening of Eocene time is not the begimuing of the sorralled Age of Mammals. but embraces a prolonged closing chapter in the Age of Reptiles.

The various kinds of eridence which may be adduced in favor of this interpretation of the succession of phenomena in North America will be presented by Dr. F. H. Knowlton, who, firsty, will demonstrate that paleobotany does not indlicate any sharp line of demarcation between the [Tpper Cretaceous ("Lance") and Jower Focene, and, secondly, he will point out the evidence, which is arepterl by a considerable number of American geologists, for the beliet that there is widespread diastrophism occurring at a certain period long before the close of the Age of Reptiles. This diastrophic movement is believed by Doctor Knowlton to correspond with the close of Cretaceous and opening of Eocene time. It occurs long before the close of the Age of Reptiles. 
The more traditional view that the sequence of life events was concurrent in America and Europe will be presented by the other speakers, who will contend that the Cretaceous terminates at the close of the Age of Reptiles and is marked by the extinction of the great terrestrial dinosaurs.

Dr. T. W. Stanton will consider the evidence of geology and invertebrate paleontology, and will endeavor to show that there is insufficient evidence of any general diastrophism prior to the close of the Age of Reptiles.

Mr. Barnum Brown will point out that the succession of Ceratopsian faunas in Upper Cretaceous time affords several distinct phases, the last of which is that of the so-called "Lance" formation, which alone contains the culminating genus Triceratops.

Dr. W. D. Matthew will compare the "Lance" and "Belly River" vertebrate faunas with those of the Paleocene of the Puerco and Torrejon, our oldest mammal-bearing horizons, and those of the Thanétien and Cernaysien beds of France and Belgium.

Dr. William J. Sinclair will describe the substitution of a rich mammalian for a terrestrial dinosaur fauna as it occurs in the succession of the Ojo Alamo (supposed Upper Cretaceous) and Puerco (supposed Paleocene) formations in northern New Mexico."

2 Doctor Sinclair's paper has been published as article xxil. vol. xxxili, Bulletin American Museum of Natural History. 1914, pp. 297-316. 
